\title{
Old versus New Politics
}

The Political Spaces in Southern Europe in Times of Crises

\author{
Swen Hutter, Hanspeter Kriesi, and Guillem Vidal \\ (European University Institute)
}

\begin{abstract}
This paper focuses on the party political spaces in four Southern European countries (i.e., Greece, Italy, Spain, and Portugal) since the onset of the Euro crisis. To understand the political changes underway, it argues for the need to consider that these countries simultaneously face an economic crisis and a political crisis, and that both crises have strong domestic and European components. Moreover, the major driving forces of change tend to be social movements and political parties from the new left. This leads to a complex conflict structure shaped by struggles over austerity and political renewal. In this structure, opposition to austerity and to 'old' politics are closely associated with each other. While this pattern emerges everywhere, there are distinct country differences. Empirically, the paper relies on original data from a large-scale content analysis of national election campaigns in the four countries in the period 2011 to 2015.
\end{abstract}

Party competition, Southern Europe, economic crisis, political crisis, new left

Draft July 2016

Pre-print version, published in Party Politics 24(1): 10-22 


\section{Introduction}

Party systems have been institutionalized to a variable extent in the different parts of Europe. In broad strokes, in the Northwest, party systems are highly institutionalized, but two waves of mobilization have significantly transformed them over the past decades - a first wave led by the new left in the 1970s and early 1980s, and a second wave driven by the new right since the 1990s. The term 'new' underscores that these actors were seen as breaking with the past and challenging the political order at that time. Most importantly, the challenge arose from new issues and demands that these actors brought into the political process. The new left advocated individual autonomy, the free choice of lifestyles and other universalistic values. The new right, by contrast, focused on immigration and European integration as threats to the homogenous nation-state. Both waves concerned above all cultural issues. That is, they primarily transformed the meaning of the cultural dimension of the two-dimensional political spaces. Interpreting the impact of the new left, Kitschelt (1994) re-baptized the cultural dimension as 'libertarianauthoritarian' dimension; focusing on the impact of the new right, Hooghe et al. (2002) chose to relabel it as 'Green/alternative/libertarian (GAL) versus traditional/authoritarian/nationalist (TAN)', while Kriesi et al. (2008, 2012) labeled it as 'integration-demarcation.'

By contrast, the party systems in Southern Europe are less institutionalized, and they have been less transformed by the two waves which had such an impact on the Northwestern European political spaces. This applies to all four countries we study in this paper - Greece, Italy, Portugal and Spain. The Southern European partisan spaces remained essentially bipolar with cultural and economic issues amalgamated in one single left-right dimension (Polk and Rovny, 2016) and parties weakly rooted in the cleavage structure (Gunther, 2005).

In this paper, we contend that with the Great Recession and the subsequent Euro crisis the configurations of the political spaces in Southern Europe are changing. However, given 
long-term trends and the way the crisis played out in the domestic arenas, we do not expect the same pattern to emerge as in Northwestern Europe - characterized by an economic and a cultural dimension, and the latter being transformed by the emergence of challengers from both the new left and right. By contrast, to understand the political changes underway in Southern Europe, we argue for the need to consider that these countries simultaneously face an economic and a political crisis which both have strong domestic and European components (see also della Porta, 2015). This should give rise to salient conflicts over both austerity and political renewal. Moreover, the key driving forces of change tend to be social movements and political parties from the new left given the discrediting of the mainstream left and the new populist right. As a consequence, we expect that opposition to austerity and 'old' politics is closely associated with each other in the political spaces and that this alignment is facilitated if the mainstream left is in opposition. In government, the mainstream left is forced to implement austerity which leads to a "neoliberal convergence" similar to the Latin America experience (Roberts, 2013), whereas it attempts to capitalize on the issues of political renewal when in opposition.

The paper is structured as follows. To prepare our argument, we first discuss the economic and political crises in the four countries. Next, we turn to the challengers in the party systems and their differing emphasis on the failures of domestic and/or European elites. This leads to more specific expectations on the emerging structure of political conflict. Third, we introduce design and methods. We focus on the nine national elections that took place in the four countries from 2011 to 2015. By doing so, we move beyond an analysis of single 'extraordinary' elections - like the Greek election in May 2012 or the Italian election in 2013 (e.g., Conti and Memoli, 2015; Katsanidou and Otjes, 2016) - in our quest to assess the political consequences of the Great Recession. Empirically, we follow the research strategy of Kriesi et al. $(2008,2012)$ and rely on a relational content analysis of media data. This original new 
dataset allows studying public debates during election campaigns and discussing our results in light of Kriesi et al.'s conclusions on the Northwest of Europe.

Overall, the findings support our expectations. Putting the accent on similarities, we find that both economic and political issues are key to understanding the structure of political conflict in Southern Europe in times of crises. All countries saw significant conflicts over austerity and old-vs.-new politics, and there is a strong association between opposition to domestic austerity and calls for democratic renewal. This pattern emerges everywhere, although its concrete manifestation varies across countries and over time depending on, amongst others, the government participation of the mainstream left.

\section{Conflicts in times of economic and political crises}

From our point of view, it is useful to combine structural and strategic approaches to party competition as they tend to complement each other (for the two approaches, see de Vries and Marks, 2012: 187ff.). As argued by the structural perspective, processes of social change create structurally defined potentials that are, as argued by the strategic approach, mobilized by strategic political actors. Of course, an approach that views party competition as ultimately rooted in structural conflicts begs the question of which social conflicts have the capacity to restructure the partisan space. Given the devastating effect of the Great Recession on the Southern European economies, we expect political conflict to focus on economics. However, for understanding the political consequences of the economic crisis it is crucial to keep in mind that Europe has developed into a multi-level governance structure and that, given the close economic interdependence of the EU member-states, the economic crisis in Europe has developed into the 'Euro crisis' (Copelovitch et al., 2016). This crisis has been mainly driven by economic imbalances between the Northwestern and Southern members of the Eurozone 
(e.g., Lane, 2012; Scharpf, 2011). The governments of the weaker, Southern European economies, in particular, were unable to cope with the crisis, and the EMU governance structures revealed their structural weakness (e.g., Eichengreen, 2012; Featherstone, 2011). The ensuing crisis management involved above all the EU's intergovernmental channel, and the European governments represented their national interest as 'debtor' (Southern European, plus Ireland) or 'creditor' (Northwestern European) nations in this bargaining process - whatever their partisan composition (e.g., Laffan, 2016).

In other words, in the 'debtor' countries, the Euro crisis gave rise to a crisis situation that greatly reminds us of the Latin American experience of the 1980s and 1990s (Lupu, 2014; Roberts, 2013). Under the pressure from the EU (represented by the 'Troika'), the national governments adopted austerity policies that were harsh for large parts of society. The model case is Greece, where the Troika intervened most manifestly and with most dramatic consequences for the country's economy. However, under the impact of the crisis, the other three countries under scrutiny became the object of supranational interventions as well. Portugal was bailed out by the IMF/EFSF in spring 2011. Spain accepted a bailout of its banks by the ESM in summer 2012. Italy, even if not formally bailed out, became the object of implicit conditionality' when it was hit by the financial storm in summer 2011.

As a result, the governments' maneuvering space in macro-economic policy-making was severely restricted, with significant political consequences at the domestic level. In Italy, the imposed austerity measures brought down the right-wing Berlusconi government and ushered in the technocratic Monti government that was supported by all three major parties. In Greece, Portugal, and Spain, the imposed austerity policies initially had to be executed by governments from the left. These governments were not able to adopt the reforms they had originally promised and were forced to take measures that contradicted the policy positions for 
which they were known in the past. In line with the Latin-American experience, the neoliberal convergence of major parties imposed by forces external to national party competition led to party brand dilution, to a decline of partisanship and, eventually, to a process of de-alignment - and, in the case of Greece, to the collapse of the incumbent party (PASOK) and even the entire party system (e.g., Verney, 2014).

The challenging of the mainstream parties under the impact of the crisis had, however, also domestic origins. Structural problems, policy errors and misconceptions predated the Euro crisis and left the Southern European countries particularly ill-prepared to respond to the crisis. All four countries are characterized by weak state capacity (Beramendi et al., 2015: 13), and even this capacity has been systematically undercut by clientelistic practices and political corruption. Greece certainly has been the worst offender with both major parties establishing a system of party patronage (Pappas and O'Malley, 2014), while the Portuguese parties have been comparatively less clientelistic (Afonso et al., 2014: 6). As Royo (2014) argues for Spain, we cannot understand the real estate bubble, the loss of competitiveness or the financial crisis without taking into account what he calls the 'institutional degeneration' in Spanish politics. However, as he also argues, the problem is both the extractive behavior of elites and that civil society tolerated such behavior. Only when the crisis exposed an unsustainable economic model, the public was outraged by the actions of its elites.

The increased perception of corruption was coupled with growing distrust towards both domestic and European political institutions (Muro and Vidal, 2016). An overall sense of frustration with the political elites captivated a large share of the population in Southern Europe and soon translated into activity in the protest arena - signs of what Mainwaring (2006) calls the attitudinal and behavioral dimensions of a political crisis. While the protests in the four countries differed in timing, size, and organizational sponsors, they emphasized similar claims 
against austerity measures and the malfunctioning of (representative) democracy (see Altiparmakis and Lorenzini, 2016; della Porta, 2015).

What does this mean for the structuration of the partisan political space? First of all, it is important to keep in mind that there are two overlapping conflicts - the conflict with the domestic elites and the conflict with the European elites. Second, each one of these conflicts has a political and an economic component. To illustrate this, Table 1 shows a four-fold table with the four combinations of conflicts and the associated issues. The domestic conflict is about austerity policies (an economic issue) and corruption and democratic renewal (a political issue). The supranational conflict, where it is present, is obviously about austerity, too, but it is also about the defense of the nation-state, about national pride and humiliation, and the democratic deficit at the European level. To sum up, we contend that the political spaces in Southern Europe reflect the economic and the political crises that have unfolded in these countries since the outbreak of the Great Recession in 2008. Thus, we formulate the following hypothesis:

Hypothesis 1: Under the impact of a two-fold crisis, conflict over economic and political issues are structuring the political spaces in Southern Europe.

[Table 1]

\section{The rise of (different) challenger parties in Southern Europe}

New challenger parties have been singled out as the driving forces of the transformation of the political space given the programmatic inflexibility of mainstream parties and their tendency to stick to the dominant dimensions of conflict (for a recent summary, see Hooghe and Marks, 2016: 2ff.). They 'translate' the latent potentials into manifest conflicts. Therefore, we briefly introduce the electorally most successful new challengers in the four countries as this allows refining our expectations. 
Once the economic crisis struck, the public reacted in a two-stage process in the electoral arena. In a first stage, incumbents were punished as predicted by the economic voting literature. The punishment was exemplary, but it was rather conventional as voters turned to the mainstream opposition party. Only in the second stage, the voters typically sanctioned all the mainstream parties and massively turned to challenger parties (e.g., Hernández and Kriesi, 2016; Hobolt and Tilley, 2016). Portugal is the only country among the four where there is no marked second stage in sight yet, even if in the 2015 elections an unprecedented 18.5 percent of the vote went to parties left of the socialist PS - the Left Bloc BE gaining the most.

In Greece, challengers from both the left and the right rose to prominence in the 2012 elections (e.g., Gemenis and Nezi, 2015; Katsanidou and Otjes, 2016; Verney, 2014). However, the Coalition of the Radical Left (Syriza) proved to be most successful, becoming the largest party in January 2015. Syriza was a left-wing opposition party that had been founded in 2004 and it established close links with the extraordinary mobilization of Greek society in the streets. Syriza, besides holding a strong anti-austerity (and initially anti-bailout) position, opposes both the domestic and the European elites. As observed by Stavrakakis and Katsambekis (2014), Syriza's discourse became clearly populist by painting a sharp antagonism between 'us' ('the people') and 'them' (the 'elite'). Tsipras, Syriza's leader, used the phrase of 'external troika internal troika'. In this way, the three-party coalition government (ND, PASOK and DIMAR) was effectively equated with the country's international emergency lenders. 'Us,' by contrast, is 'every democratic citizen,' held together by a common democratic struggle with a common cause, that is, the overthrow of two-partyism and austerity policies. Also, Stavrakakis and Katsambekis (2014: 132) point out that Syriza's populism tends to be inclusionary. They highlight that Syriza has been "one of the most consistent advocates of the immigrants' equal rights and their full inclusion in Greek society" (p. 132). Syriza also supports common claims of the new social movements of the 1970s such as gender equality and LGTB rights. 
In Spain, too, challengers rose both on the left (Podemos) and in the center (Ciudadanos). Although the electoral results do not differ as much as in the Greek case, the new left challenger, Podemos, is so far also more successful than its center-right rival (e.g., Ramiro and Gomez, 2016). ${ }^{1}$ Podemos has grown out of the social movements of the squares. It was founded early in 2014 and had its first success in the European elections in March 2014. In the 2015 general elections, it obtained 20.7 percent of the votes. Podemos, as opposed to Syriza, is more focused on the national elite and less anti-European. While at variance with the old Communist left, this is in line with the tradition of the Spanish mainstream left for whom Europe provided relief and shelter from the fascist past (see Díez-Medrano, 2003). In unmistakably populist manner, the party claims to defend the 'social majority' ('mayoria social'), the 'power of the people' ('poder popular') or simply the 'citizenship' ('ciudadania') against the degenerated 'casta' of politicians (e.g., Bernhard and Steenbergen, 2016; Ramiro and Gomez, 2016). But Podemos is not anti-European. Despite its anti-austerity positions, its program is conscious of the fact that some of its demands can only be implemented in the European context. Thus, the party proposes a new 'Carta Democrática Europea', which intends to provide citizens with greater participation in European policy-making and ethnic minorities, such as the Catalans, with self-determination.

In Italy, the new challenger, the five star movement (M5S), is harder to situate, since it claims to be neither left nor right. ${ }^{2}$ It began a startling rise in opinion polls from below six percent in April 2012 and obtained no less than 25.6 percent of the vote in the national election

\footnotetext{
${ }^{1}$ Ciudadanos was formed in summer 2006. It has grown out of Catalonian civil society and has been mainly active in Catalonia, where it opposes Catalonian nationalism (Rodríguez Teruel and Barrio, 2015). The focus on domestic elites is equally if not more pronounced with Ciudadanos than with Podemos. Their ideas concern above all domestic reforms (of the party system, the legal system, public administration and internal decentralization) as well as economic and social policy, but they have little to say about the EU. Although Podemos and Ciudadanos differ in ideological terms, their voters share a set of socio-demographic (younger, more educated, socio-cultural professionals, urban) and attitudinal traits that points to the fact that both parties represent those particularly concerned with the economic and political crisis in Spain (Vidal, 2016).

${ }^{2}$ As a matter of fact, the Spanish Podemos, although clearly to the left, adopted a similar strategy as M5S claiming to neither left nor right in order to capture the centre of the political spectrum.
} 
in spring 2013. As electoral studies show, it took votes from the left and the right (e.g., Bobba and McDonnell, 2015: 172; Ceccarini and Bordignon, 2016: 143). In its program, the party casts the citizens of Italy as the victims of a system captured by corrupt and incapable elites at the national and supranational level. The blame is firmly laid on the shoulders of Italy's entire ruling class (comprising all existing parties, the media, and business leaders) and European elites, to whom the party attributes the malfunctioning of democracy and the economy's decline. By contrast, M5S exalts the 'good' citizens (i.e. 'the people') whose well-being and democratic rights are oppressed by the elite (e.g., Bobba and McDonnell, 2015). To remedy the situation, M5S proposes to overturn the system, removing the current elites and restoring power to the Italian citizen by online direct democracy. As many of its supporters have defected from the right, the Italian M5S, at first sight, seems to fit least into the new left category (Ceccarini and Bordignon, 2016: 154). However, this challenger, too, has some features in common with the new social movements and the parties they spawned. As Biorcio $(2014,37 ; 2015,121)$ has observed, in many ways (especially with its calls for a participatory and deliberative democracy), this movement recalls the German Greens thirty years ago.

Based on the programmatic profile of the new challengers, we can specify our expectation further. Overall, the new challengers in Southern Europe - like their counterparts in the North - raise specific policy demands, but they also pose a challenge to the established system of interest intermediation more generally. To a certain extent, they combine the new left's call for participatory democracy and its reliance on protest politics with the new right's populist appeal. The most prominent challengers are from the political left (Syriza and Podemos) or center-left (M5S) - a left that generally defends positions in favour of state intervention on economic issues and universalistic positions on cultural issues. 
The central role of social movements and political parties from the new left seems due to the discrediting of both the new populist radical right and the mainstream left, and it mirrors the pre-crisis situation as leftist challengers have traditionally been stronger in the South of Europe than in the Northwest (Hooghe and Marks, 2016: 15). The new right was largely discredited by the authoritarian legacy, the fact that immigration has hardly been an issue in these emigration countries until recently and that European integration was essentially seen in positive terms (see above). Moreover, the programmatic dealignment of the mainstream left resulting from the 'forced' implementation of a neoliberal program opened up a niche for new leftist challengers that campaign on an anti-austerity agenda. Thus, we argue that challengers from the left had the advantage to capitalize on both conflicts through combining an anti-austerity message with a need for regenerating the political system in general. Thus, we expect that the relationship between the conflicts shown in Table 1 are not orthogonal to each other. Rather, we expect an alignment of opposition to austerity and calls for democratic renewal on the left side of the space. This alignment should be facilitated if the mainstream left is in opposition. In government, the mainstream left is forced to implement austerity. By contrast, we expect that it attempts to capitalize on the issues of political renewal while in opposition. To sum up, we formalize the discussion in two hypotheses:

Hypothesis 2: Economic and political conflicts are closely aligned in the political spaces in Southern Europe given that challengers from the new left are the driving forces of change.

Hypothesis 3: The alignment of the two types of conflicts in the political spaces in Southern Europe is facilitated if the mainstream left is in opposition

\section{Design and methods}

In the following, we introduce the design, data, and strategy of data analysis (a more detailed methodological discussion can be found in the Appendix). We adopt a most different systems 
design as we are most interested in carving out what is similar in the structure of the political spaces in the four countries taking into account that they differ in many respects (from the electoral systems to the strength of other traditional cleavages, such as the center-periphery cleavage). Moreover, the previous sections have already pointed to crucial differences regarding both the latent potentials and the actors who articulate them, i.e., the extent to which the two crises affected the countries under scrutiny and the types of new party challengers that have been emerging. The campaigns covered by the analysis took place when the Euro crisis was in full swing. More precisely, we focus on the four Greek elections in May and June 2012 and in January and September 2015; the Italian election in 2013; and the Portuguese and Spanish elections in 2011 and 2015.

To analyze party competition during electoral campaigns, we follow the strategy of Kriesi et al. $(2008,2012)$ and make use of a relational content analysis of newspaper articles. This strategy allows us to study the publicly visible contestation among the political parties during the campaigns and map the issues of the day onto broader issue dimensions to test our claims about the structure of the political space. The analysis is based on the coding of two newspapers per country. To avoid ideological biases, we selected two quality newspapers per country, one each from the center-left and the center-right: Ta Nea and Kathimerini (Greece), La Repubblica and Corriere della Sera (Italy), Público and Diário de Notícias (Portugal), and El Pais and El Mundo (Spain). We then coded a sample of the selected articles using core sentence analysis (CSA). Following this type of relational content analysis, each grammatical sentence of an article is reduced to its most basic 'core sentence(s)' structure, which contain(s) only the subject, the object, and the direction of the relationship between the two. For the following analysis, we rely on all relations between party-affiliated actors as subject and any political issue as object. Overall, the analysis is based on around 11,000 such actor-issue statements (see Table A.1). 
A crucial step in our analysis is aggregating the detailed issues that were coded into a set of broader categories. The aggregation was guided by two considerations: (a) to capture the general conflicts described in the previous sections and (b) to compare our results to previous findings of Kriesi et al. (2008, 2012). More specifically, we regrouped the detailed issues into eighteen categories (for detailed descriptions, see Table A.2 in the Appendix). For the analysis, the first eleven categories are most important as they allow us to distinguish economic from political issues, and domestic from European references. Economic issues are covered by the categories welfare, economic liberalism, economic reforms (vague), Euro, anti-bailout and anti-bailout (conditions). Political issues are covered by the categories democratic renewal, democratic reforms (vague), regionalism, media diversity, and Europe. Note that European issues need to refer explicitly to the European dimension of the question at stake. Thus, we cover under this label all debates about (political) EU integration in general (including enlargement), as well as specific (economic) statements about the Euro, the bailouts and their conditionality. The coded actors are aggregated according to their party affiliation.

The data proceeds in two steps. At first, we present simple measures of issue salience and polarization. Salience is measured by the share of core sentences related to an issue category in percent of all coded sentences. The indicator for the polarization of party positions is based on a modified version of Taylor and Herman's index of left-right polarization in the party system, and it ranges from 0 to 1 (for its calculation, see Appendix). We analyze both measures because conflicts over a given issue should not only be highly visible in the public debate, but they should also lead to a relatively polarized situation to structure the dimensions of the political space. That is, parties should take clearly different positions regarding the issue.

In the second part, we study the spatial configurations. Following Kriesi et al. (2008, 2012), we construct the spaces based on the coded issue statements with the help of multi- 
dimensional scaling (MDS). MDS allows graphically representing the location of parties and issues in a common low-dimensional space. It helps to identify whether and how conflicts over different issues map onto some underlying dimensions (a more technical description can be found in the Appendix). As in any spatial analysis, the focus on dimensions comes at the expense of details. That is, MDS allows identifying main lines of opposition in the party system like under a magnifying glass. The tradeoff is that less salient issues and actors are less accurately represented. MDS configurations can only be interpreted regarding distances between objects. The orientation of a configuration is arbitrary, which implies that it can be freely rotated. To facilitate comparison of the spaces shown below, we have rotated them in such a way that the issues 'welfare' and 'economic liberalism' are situated on a horizontal line. To focus attention on those aspects of these configurations that are most important given our hypotheses, we have added four graphical elements. First, we have drawn a line connecting welfare and economic liberalism as the supposed endpoints of the economic left-right divide. Second, we have introduced circles of varying size around the points identifying issues and parties to indicate their respective salience. Third, we added a line connecting 'anti-bailout' and 'proeuro' for the Greek elections, and a vertical dashed line at the mid-point of the left-right divide for all other elections. Finally, we have added a circle that covers the main left-wing challengers and the issue of 'democratic renewal.' This circle is added to facilitate the interpretation of our results regarding the alignment of opposition to 'old politics' and conflicts over austerity.

\section{Empirical findings}

To assess the importance of conflicts over economic and political issues, we first look at the average salience of the principal categories by country. As expected, the results in Table 2 show that the campaigns are highly focused on economic issues in times of a severe financial 
and economic crisis. The partisan debate is most concentrated on economics in Portugal (with more than two-thirds of all statements) and the least in Spain (with around forty-four percent). ${ }^{3}$ By contrast, Portugal saw the least salient conflicts over political issues. In part, this might be because there was no new party emerging out of the movements in the squares in Portugal. In the other three countries, conflicts over political issues account for around one-third of all issue statements by parties reported in the press.

The focus of the agenda on economic matters seems not as surprising during an economic crisis (see also Borghetto and Russo, 2016). However, the relatively high salience of political issues supports our first hypothesis: under the impact of contemporaneous crises, the political actors are involved in struggles over both austerity and ways to improve the quality of the democratic process. By contrast, other kinds of substantive policy issues (ranging from cultural liberalism to immigration and environmental protection) do not get much attention in the mass-mediated partisan debate, which contrasts with previous findings of Kriesi et al. (2008, 2012) for Northwestern Europe.

[Table 2]

On the role of Europe in the debates, the findings in Table 2 are striking as, apart from Greece, the campaigns do not constitute critical moments in the politicization of Europe. This result contradicts the expectations of some observers (e.g., Schimmelfennig, 2014; Statham

\footnotetext{
${ }^{3}$ Analysing the single campaigns shows that the low salience of economic issues in Spain is due to the 2015 campaign in which political issues trumped over economic ones. In the 2011 campaign, by contrast, the focus was as much on economic policies as in Portugal or Greece. In Greece and Portugal, we do not observe such pronounced shifts over time, although the Portuguese campaign in the autumn 2015 was less focused on political issues, whereas the latest Greek campaign around the same time centred more on such topics compared to the other Greek campaigns covered by our analysis (see Table A.3 in the Appendix).
} 
and Trenz, 2015). Explicit references to European issues amount to less than ten percent in Portugal - with much higher values in 2011 when the country had just accepted its bail-out agreement - and even less than five percent in Italy and Spain. In the latter two countries, we rather find constellations of 'strategic de-emphasizing' of the European issue in the national electoral arena (Hutter et al., 2016), which is in line with the predominant focus on the failures of the domestic political class outlined above. For Spain and Portugal, it might also reflect the fact that Europe was traditionally seen as a modernizing and democratizing force (DíezMedrano, 2003).

By contrast, and in line with Katsanidou and Otjes' (2016) case study, references to European economic (i.e., Eurozone membership, the bailout and its conditions) and political issues were very salient in the partisan debate in Greece. The emphasis on European issues in Greece mirrors the fact that the country was at the center of the Euro crisis in many respects. Thus, Greece was involved in negotiations with its European and international lenders throughout the period covered. The high salience of Europe also concurs with the idea that Syriza had a more clear dual strategy of criticizing both the failures of the domestic and European elites. This result does not mean that the struggles over economic and political reforms in the other three countries did not take place in the 'shadow' of European constraints. However, the extent to which the European component was explicitly articulated in the electoral arena clearly sets Greece apart.

To examine the structuring capacity of an issue (i.e., the combination of salience and polarization), we now turn to the eighteen specific issue categories outlined above. Figure 1 shows the two measures by issue and country in a simple scatter plot. The horizontal dimension refers to salience, the vertical dimension to polarization. To ease interpretation, we added lines that indicate the respective means across all issues and countries. The critical issues are the 
ones in the upper right-hand corner of the figure, i.e. the issues that combine an above average salience with an above average polarization. Overall, Figure 1 lends additional support to our first hypothesis as conflicts over both economic and political issues are structuring political conflict in Southern Europe. In this respect, it is most significant that the issue of 'democratic renewal' (mainly focused on institutional change and on fighting corruption and clientelism) gave rise to highly salient and polarized debates in all countries. Also, 'economic liberalism' is also situated in the upper-right corner in Figure 1 in all countries expect Italy.

[Figure 1]

Apart from these similarities, there are marked differences in the type of economic and political issues that were structuring conflicts in the electoral arenas. For Greece, the results again underline the highly contested status of all European issue categories - both economic and political. For Portugal, we observe conflicts over the general need for economic reforms, the bailout (mainly in 2011) and welfare state reforms (primarily in 2015). In Italy, cultural liberalism - in particular, gender equality and gay rights - led to fairly polarized and salient conflicts, too. Finally, Spain stands out for contestation related to regionalism (dominating the 2015 campaign) and the welfare state. We cannot present detailed accounts of the various conflicts in this paper. Rather, we want to emphasize here that cultural liberalism in Italy is the only case in which an issue not covered by one of our two broad issue categories - economic or political - was the object of salient and polarized debates. In combination with the absence of immigration among the key contested topics, this points to a crucial difference to the party systems in Northwestern Europe. 
So far, we have described the most salient and polarized issues in the campaigns, but what we are most interested in is the way the various conflicts relate to each other, i.e., how they structure the political space. As explained in the methods' section, we rely on MDS to represent the distances between parties and issues graphically. Figure 2 presents the respective configurations for each country and election separately.

In general, the MDS procedure resulted in two-dimensional solutions for all campaigns covered by the analysis (see Figure 2). The major dimensions of the partisan spaces in Southern Europe tend to be characterized by amalgamated conflicts over economic and non-economic issues (see also Rovny and Polk, 2016; Tsatsanis et al., 2014). More precisely, we find support for our second hypothesis: conflicts over austerity and democratic renewal do not represent independent orthogonal dimensions. Instead, apart from Italy, we observe that opposition to austerity and 'old' politics are aligned in the political space: the new challenger parties are closely associated with both types of opposition. This result is illustrated in Figure 2 by the fact that the circle that covers the left-wing challengers and the issue 'democratic renewal' is located at the left-wing pole of the economic divide in all countries except for Italy. A key difference is that, in the case of Greece, the main economic conflicts revolve around European measures, but around domestic measures in the other three countries. To substantiate these general remarks, let us take a look at each country in detail.

In Greece, the spaces in all four campaigns are structured around conflicts over domestic and European austerity, as well as over democratic renewal (Figure 2a). While the resulting configuration is two-dimensional, it is the EU bailout/anti-bailout conflict that dominates the 2012 campaigns and the one in January 2015 as indicated by the spread of all parties along this dimension (see also Katsanidou and Otjes, 2016). We have highlighted this main line of con- 
flict by connecting the issues of 'anti-bailout' and '(pro-)euro. ${ }^{4}$ However, as we want to emphasize here, this conflict overlaps with the divide between the parties that stand for new politics and those that stand for the 'old corrupted political class.' As can be seen in Figure 2a, the two established mainstream parties, PASOK and New Democracy, are closely associated with the pro-bailout/anti-democratic renewal pole, while there is a diverse camp of left-wing (KKE and Syriza) and right-wing (ANEL and Golden Dawn) challengers located at the antibailout/pro-democratic renewal pole in the May 2012 campaign.

[Figure 2a]

The spatial configuration changed in autumn 2015 when Syriza (now in government) supports the third bailout agreement. For this campaign, Figure $2 \mathrm{a}$ indicates that the main line of conflict is a kind of transformed left-right dimension with Syriza as the main party on the left (close to welfare and democratic renewal) and New Democracy as its main opponent situated close to economic liberalism. Of course, the bailout/anti-bailout division has not disappeared. However, with the schism within Syriza that led to the formation of the new splinter party 'Popular Unity' in the run-up to the fall 2015 elections, the bailout issue no longer overlaps as much with the 'new vs. old politics' divide. The graph for the second 2015 campaign shows that KKE and Popular Unity still share their support for democratic renewal with Syriza, but that they have by now become the most visible opponents of the bailout.

\footnotetext{
${ }^{4}$ In Greek crisis elections, the classic version of the left-right divide between pro-welfare and economic liberalism is of secondary importance. On the one hand, the secondary status of this divide is due to the rather low salience of welfare-related questions and, most importantly, because the Greek parties tend to agree on a minimum level of welfare protection (in the sense of fighting poverty and supporting social aid) and they all don't fully embrace the idea of economic liberalism and budgetary rigor at the national level.
} 
In Spain, we observe a different configuration which reflects the fact that European issues were hardly debated neither in 2011 nor 2015 (Figure 2b). The 2011 campaign is characterized by a two-dimensional structure, although one dimension dominates the configuration. This divide separates the mainstream left (PSOE) from the mainstream right (Partido Popular PP). It combines conflicts over welfare and economic liberalism with conflicts over cultural liberalism and defense. The secondary dimension is characterized by questions of regionalism and European integration. As shown in Figure 2b, the radical left (IU) and the newly created social-liberal Union, Progress and Democracy (UPyD) are closest to democratic renewal in the 2011 election, while the two mainstream parties in opposition and government are equally distant to it. In 2015, we observe even more polarization on the economic left-right divide (with PP moving closer to economic liberalism and PSOE closer to welfare). This time, the second dimension in Spain is mainly based on regional conflicts in general and Catalonian independence in particular. ${ }^{5}$ However, most importantly for our argument, there is an even stronger integration of the issue 'democratic renewal' on the left of the economic divide. This becomes obvious when looking at the positioning of the new left-wing challenger Podemos. It is located very close to welfare and democratic renewal. Also, Figure $2 \mathrm{~b}$ indicates that, as expected by our third hypothesis, as an opposition party the socialist PSOE has moved to the left and is now closely associated with democratic renewal, criticizing corruption and clientelism (notwithstanding related problems in its own ranks).

[Figure 2b]

\footnotetext{
${ }^{5}$ While Podemos was in favour of a referendum and more regional autonomy, the other parties - especially PP were more opposed to such ideas, as indicated by the fairly large distance of their position to the regional issue. Another minor issue on this secondary dimension was defence, as Ciudadanos and Podemos had different opinions about military interventions debated in reference to the anti-jihadist pact after the Paris attacks a month before the 2015 elections.
} 
The case of Italy in 2013 presents yet another manifestation of how support for democratic renewal and opposition to the old political class is embedded in the political space. The Italian configuration in Figure 2c comes closest to a two-dimensional space with two orthogonal lines of conflict (see also Conti and Memoli, 2015). The first dimension, which is dominated by conflicts over economic liberalism (especially labor market reforms), represents the economic left-right divide. Conflicts over democratic renewal, cultural liberalism, and European integration are embedded in the second dimension. As shown before, the main competitors in the party system - ranging from the Social Democrats (PD) via Berlusconi's People of Freedom (PDL) to Monti's Civic Choice (SC) - are all placed rather closely together in the middle of the economic divide. This reflects the fact that they had all backed at least part of the reform agenda implemented by Monti's (incumbent) technocratic government. M5S is also positioned in the center of this divide, far away from economic liberalism and further away from welfare than the two mainstream parties from the left and the right. In the 2013 campaign, its economic program did not attract much attention, and it backed incoherent proposals anyway (Ceccarini and Bordignon, 2016: 147ff.). The movement is mainly associated with its opposition to the 'casta' and calls for democratic renewal - highlighted by the small size of the circle connecting it with this issue category. While the PD and the SC share some of the claims for democratic renewal, the main culprit on this dimension is Berlusconi's party, the PDL, which is located most distant from the issue of democratic renewal.

[Figure 2c] 
Finally, for Portugal, Figure 2d shows different configurations in 2011 and 2015 which has a lot to do with the timing of the bailout in the country and government-opposition dynamics. The Socialists (PS) lost the 2011 election and were succeeded by a mainstream right-wing coalition formed by the Social Democrats (PSD) and the Conservatives (CDS). As indicated by Figure $2 d$, the structure of the political space is two-dimensional for the 2011 campaign. As in Spain and Italy, we observe an economic left-right dimension (indicated by the straight horizontal line). The right, PSD and CD, are situated close to economic liberalism and the radical left, BE and PCP, close to welfare. The governing Socialists are also located at some distance from economic liberalism. Their support for the bailout agreement and attacks from their opponents (blaming them for the political crisis in the country) open up the second dimension. This second dimension mainly results from a split within the left between the radical left in opposition and the incumbent Socialists. The situation is very different in 2015 when economic issues divide a unified left from a unified right, with issues relating to institutional change being embedded on the left-hand side of this one dimension. The fact that the PS was now in the opposition apparently facilitated the unified position of the left not only regarding the economic but also regarding the political conflict (supporting our third hypothesis). ${ }^{6}$

[Figure 2d]

\footnotetext{
${ }^{6}$ The dominance of such an integrated dimensions is in line with findings of Tsatsanis et al. (2014) based on an elite survey during the respective legislative term. The second dimension in the 2015 election campaign is of secondary importance, since the parties do not much address the two issues constituting this dimension (European integration and immigration) and since they are all equally opposed to tougher immigration policies.
} 


\section{Conclusions}

We have assessed the partisan political spaces in four Southern European countries (i.e., Greece, Italy, Spain, and Portugal) in the Euro crisis. We have developed the argument that, to understand the politics of the crisis, one needs to consider that the countries simultaneously face an economic and a political crisis - a crisis of representation that opposed the 'old' political elite to 'new' challengers. We also argued that both crises have strong domestic and European components and that the main driving forces of change tend to be social movements and political parties from the new left. As a result, we expected a particular structure of the political spaces in Southern Europe characterized by the close alignment of conflicts over economic and political issues. Empirically, we have relied on original media data from a relational content analysis of the partisan debate during the nine election campaigns that took place in the four countries from 2011 until the end of 2015.

We can draw at least four key findings from our analysis: First, putting the accent on similarities, we do find support four our claim that both economic and political issues are key to understanding the structure of political conflict in Southern Europe in the early 2010s. All countries saw significant combinations of conflicts over austerity and old-vs.-new politics, and we found a strong alignment of opposition to domestic austerity and calls for democratic renewal in the political spaces. Second, this alignment tends to be stronger if the mainstream left is in opposition. In government, the mainstream left is forced to implement austerity policies, whereas it attempts to adopt economically more left-wing positions and capitalize on the issues of political renewal when in opposition. The Portuguese and Spanish elections in 2015 are telling examples of this mechanism. Third, the structuration of political conflict that is shaping up in all four cases differs from the structuration we found in the Northwest of Europe. In Northwestern Europe, the driving force for the most recent transformations of party competition has come from the new populist right and the conflict structure is characterized by 
the double impact of the challenges of European integration (perceived as a threat to the sovereign nation state) and immigration (perceived as a threat to the national identity). In the Southern European countries, we have only observed sustained references to the European component of the conflicts in the Greek case. Moreover, the focus on the bailout and its conditions did not politicize Europe in a cultural-identitarian way, but rather replaced the economic left-right divide by a new divide related to European austerity (at least until autumn 2015). Fourth, there are other major differences in the way the latent potentials induced by the crises have so far been politically articulated in the various countries and in the way they are embedded in pre-existing political divides. Thus, far from claiming that there is a uniform political space in Southern Europe, we have just pointed to the commonalities in this paper. Based on our results, future research should describe and explain in more detail the different manifestations of the general argument.

While it may be too early to foretell the outcome of the transformation of the conflict structure in the Southern European party systems, we would like to end with some speculations. As we interpret the configurations that have been shaping up in the last elections, it is crucial that the main thrust of the new challengers has come from the left. To the extent that the new challengers from the left dominate the scene, they are the drivers of the integration of the call for democratic renewal into the traditional division between the economic left and the economic right. We can see this happening in Greece, where the democratic renewal is clearly associated with the left. Even if the radical left is divided over the issue of the bailout and the euro, it is united in its call for democratic renewal. Syriza's dominating position on the left is a factor that suggests that the second dimension, which is constituted by the supranational target in the case of Greece, will fade with time and a new left is likely to replace the old left both in its socialist (PASOK) and in its communist (KKE) guise. We can also see this happen- 
ing in Spain and Portugal, where the fact that the socialists were in opposition in the last elections has helped to unify the positions of the new challengers of the left with those of the old left on the political conflict of democratic renewal. In Spain, even the new challengers from the center-right (Ciudadanos) have been drawn to the left as a result of their call for democratic renewal. Given that the new left challengers have not, as in Greece, become the dominant parties on the left in these countries (yet), a lot will depend on the capacity of the old left parties to renew themselves (in coalition or not with the new left). In Italy, finally, the waters have been muddied by the fact that there has been only one 'crisis' election so far. Also, this election has been following up on a technocratic government with which all the major parties were associated. As a result, the political conflict has been the prime mover of the structuration of the party system in the 2013 elections. The new challenger called itself "neither from the left nor the right', but if our hunch is correct, it is the functional equivalent of the new left parties in the other three countries, and its call for democratic renewal is aligning it with the forces on the (center-)left in the long run. 


\section{References}

Afonso, A, Zartaloudis S and Papadopoulos Y (2014) How Party Linkages Shape Austerity Politics: Clientelism and Fiscal Adjustment in Greece and Portugal during the Eurozone Crisis. Journal of European Public Policy 22 (3): 315-34.

Altiparmakis A and Lorenzini J (2016). Protest waves in Southern Europe. Unpublished manuscript.

Beramendi P, Häusermann S, Kitschelt H and Kriesi H (2015) Introduction. In: Beramendi P, Häusermann S, Kitschelt $\mathrm{H}$ and Kriesi H (eds) The Politics of Advanced Capitalism. Cambridge: Cambridge University Press, pp. 1-64.

Bernhard L and Steenbergen M (2016). Populism in times of crisis: Southern Europe in a comparative perspective. Unpublished manuscript.

Biorcio R (2014) The Reasons for the Success and Transformations of the 5 Star Movement." Contemporary Italian Politics 6 (1): 37-53.

Biorcio R (2015) Il Populismo Nella Politica Italiana : Da Bossi a Berlusconi, Da Grillo a Renzi. Milano: Mimesis.

Bobba G and McDonnell D (2015) Italy: a Strong and Enduring Market for Populism. In: Kriesi H and Pappas T (eds) European Populism in the Shadow of the Great Recession. Colchester : ECPR Press.

Borghetto E and Russo F (2016) The determinants of party issue attention in time of crisis: the erosion of the party mandate model. Unpublished manuscript.

Ceccarini L and Bordignon F (2016) The five stars continue to shine: the consolidation of Grillo's 'movement party' in Italy'. Contemporary Italian Politics 8(2): 131-159.

Conti N and Memoli V (2015) The Emergence of a New Party in the Italian Party System: Rise and Fortunes of the Five Star Movement. West European Politics 38 (3): 516-34.

Copelovitch M, Frieden J and Walter S (2016) The Political Economy of the Euro Crisis. Comparative Political Studies 49(7): 811-840

della Porta D (2015) Social Movements in Times of Austerity. Cambridge: Polity Press.

de Vries CE and Marks G (2012) The struggle over dimensionality: A note on theory and empirics, European Union Politics 13(2): 185-193.

Díez-Medrano J (2003) Framing Europe. Princeton: Princeton University Press.

Eichengreen B (2012) European Monetary Integration with Benefit of Hindsight. JCMS: Journal of Common Market Studies 50 (s1): 123-36.

Featherstone K (2011) The JCMS Annual Lecture: The Greek Sovereign Debt Crisis and EMU: A Failing State in a Skewed Regime. JCMS: Journal of Common Market Studies 49 (2): 193-217.

Gemenis K and Nezi R (2015) Government-Opposition Dynamics during the Economic Crisis in Greece. The Journal of Legislative Studies 21 (1): 14-34.

Gunther, R (2005) Parties and Electoral Behavior in Southern Europe. Comparative Politics 37 (3): 253-75.

Hernández E and Kriesi H (2016) The Electoral Consequences of the Financial and Economic Crisis in Europe. European Journal of Political Research 55 (2): 203-224.

Hooghe L and Marks G (2016). Europe's Crises and Political Contestation. Unpublished manuscript.

Hooghe L, Marks G and Wilson C (2002) Does Left/Right Structure Party Positions on European Integration? Comparative Political Studies 35(8): 965-989.

Hobolt S and Tilley J (2016) Fleeing the centre: the rise of challenger parties in the aftermath of the euro crisis. West European Politics 39 (5): 971-991.

Hutter S, Grande E and Kriesi H (eds) (2016) Politicising Europe: Integration and Mass Politics. Cambridge: Cambridge University Press. 
Katsanidou A and Otjes S (2016) How the European Debt Crisis Reshaped National Political Space: The Case of Greece. European Union Politics 17 (2): 262-284

Kitschelt, H (1994) The Transformation of European Social Democracy. Cambridge: Cambridge University Press.

Kriesi H, Grande E, Dolezal M, et al. (2012) Political Conflict in Western Europe. Cambridge: Cambridge University Press.

Kriesi H, Grande E, Lachat R, et al. (2008) West European Politics in the Age of Globalization. Cambridge: Cambridge University Press.

Laffan B (2016) Core-periphery dynamics in the Euro Area: from conflict to cleavage? In Magone JM, Laffan B and Schweiger C (eds) Core-periphery relations in the European Union. London: Routledge, pp. 19-35.

Lane, PR (2012) The European Sovereign Debt Crisis. Journal of Economic Perspectives 26 (3): 49-68.

Lupu N (2014) Brand Dilution and the Breakdown of Political Parties in Latin America. World Politics 66 (4): 561-602.

Mainwaring S (2006) The Crisis of Representation in the Andes. Journal of Democracy 17 (3): 13-27.

Muro D and Vidal G (2016) Political Mistrust in Southern Europe since the Great Recession. Mediterranean Politics. OnlineFirst doi: 10.1080/13629395.2016.1168962.

Pappas T and O'Malley E (2014) Civil Compliance and "Political Luddism": Explaining Variance in Social Unrest During the Crisis in Ireland and Greece. American Behavioral Scientist 58 (12): 1592-1613.

Polk J and Rovny J (2016) Worlds of Welfare and Multidimensional Party Competition in Europe. Unpublished manuscript.

Ramiro L and Gomez R (2016). Radical-Left Populism during the Great Recession: Podemos and Its Competition with the Established Radical Left. Political Studies. OnlineFirst doi: $10.1177 / 0032321716647400$

Roberts K (2013) Market Reform, Programmatic (De)alignment, and Party System Stability in Latin America. Comparative Political Studies 46 (11): 1422-52.

Rodríguez Teruel J and Barrio A (2015) Going National: Ciudadanos from Catalonia to Spain. South European Society and Politics. OnlineFirst doi: 10.1080/13608746.2015.1119646.

Royo S (2014) Institutional Degeneration and the Economic Crisis in Spain. American Behavioral Scientist 58 (12): 1568-91.

Scharpf FW (2011) Monetary Union, Fiscal Crisis and the Pre-Emption of Democracy. Journal for Comparative Government and European Policy 9 (2): 163-98.

Schimmelfennig F (2014) European Integration in the Euro Crisis: The Limits of Postfunctionalism. Journal of European Integration 36 (3): 321-37.

Statham P and Trenz HJ (2015) Understanding the Mechanisms of EU Politicization: Lessons from the Eurozone Crisis. Comparative European Politics 13 (3): 287-306.

Stavrakakis Y and Katsambekis G (2014) Left-Wing Populism in the European Periphery: The Case of SYRIZA. Journal of Political Ideologies 19 (2): 119-42.

Tsatsanis E, Freire A and Tsirbas Y (2014) The Impact of the Economic Crisis on the Ideological Space in Portugal and Greece: A Comparison of Elites and Voters. South European Society and Politics 19(4): 519-540.

Verney S (2014) Broken and Can't be Fixed': The Impact of the Economic Crisis ion the Greek Party System' The International Spectator 49(1): 18-35).

Vidal G (2016) Challenging Business as Usual? The Rise of New Parties in Spain in Times of Economic Crisis. Unpublished manuscript. 
Tables and Figures

Table 1: (Expected) Conflicts in Southern Europe

\begin{tabular}{|l|c|c|}
\hline & Economic & Political \\
\hline Domestic & $\begin{array}{c}\text { Domestic austerity } \\
\text { Welfare, economic liberalism }\end{array}$ & $\begin{array}{c}\text { Domestic democratic renewal } \\
\text { Democratic reforms, corruption }\end{array}$ \\
\hline European & $\begin{array}{c}\text { European austerity } \\
\text { Euro, bailout and its conditions }\end{array}$ & $\begin{array}{c}\text { European integration } \\
\text { European integration, deepening }\end{array}$ \\
\hline
\end{tabular}


Table 2: Issue salience by major issue categories

\begin{tabular}{lrrrr}
\hline & Spain & \multicolumn{1}{c}{ Italy } & Greece & Portugal \\
\hline Economic & $\mathbf{4 4 . 1}$ & $\mathbf{5 1 . 2}$ & $\mathbf{6 0 . 4}$ & $\mathbf{6 7 . 5}$ \\
Domestic (1) & 42.7 & 50.0 & 30.4 & 58.9 \\
European (2) & 1.4 & 1.2 & 30.0 & 8.6 \\
& & & & \\
Political & $\mathbf{3 5 . 8}$ & $\mathbf{3 4 . 0}$ & $\mathbf{2 8 . 1}$ & $\mathbf{1 4 . 9}$ \\
Domestic (3) & 35.1 & 30.6 & 20.8 & 13.9 \\
European (4) & 0.7 & 3.4 & 7.3 & 1.0 \\
Others (5) & 20.1 & 14.8 & 11.5 & 17.7 \\
European (2+4) & $\mathbf{2 . 1}$ & $\mathbf{4 . 5}$ & $\mathbf{3 7 . 3}$ & $\mathbf{9 . 6}$ \\
\hline (N) & $(2,142)$ & $(1,521)$ & $(4,002)$ & $(2,947)$ \\
\hline
\end{tabular}


Figure 1. Issue salience and polarization by specific issue categories

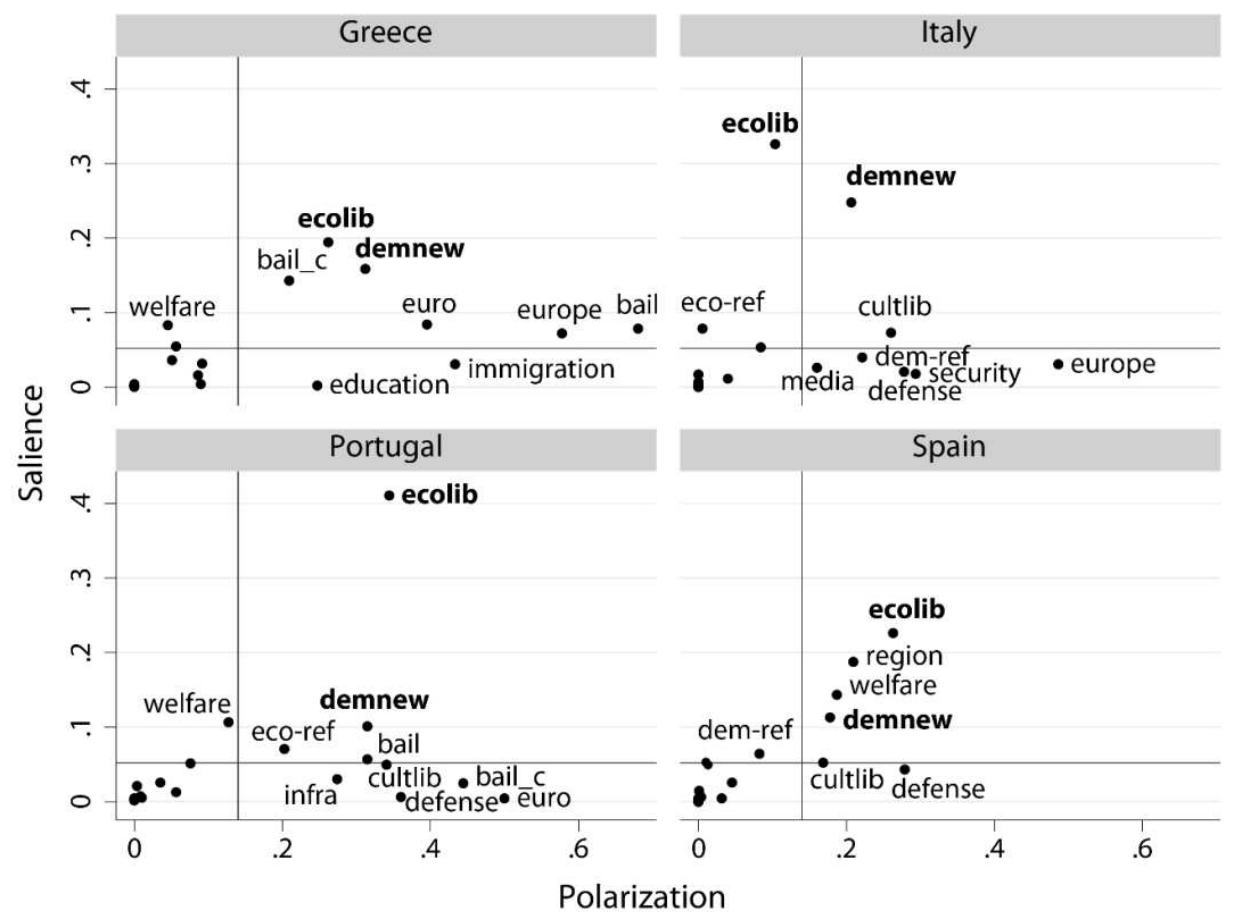


Figure 2: Political spaces in Southern Europe, 2011 to 2015

(a) Greece

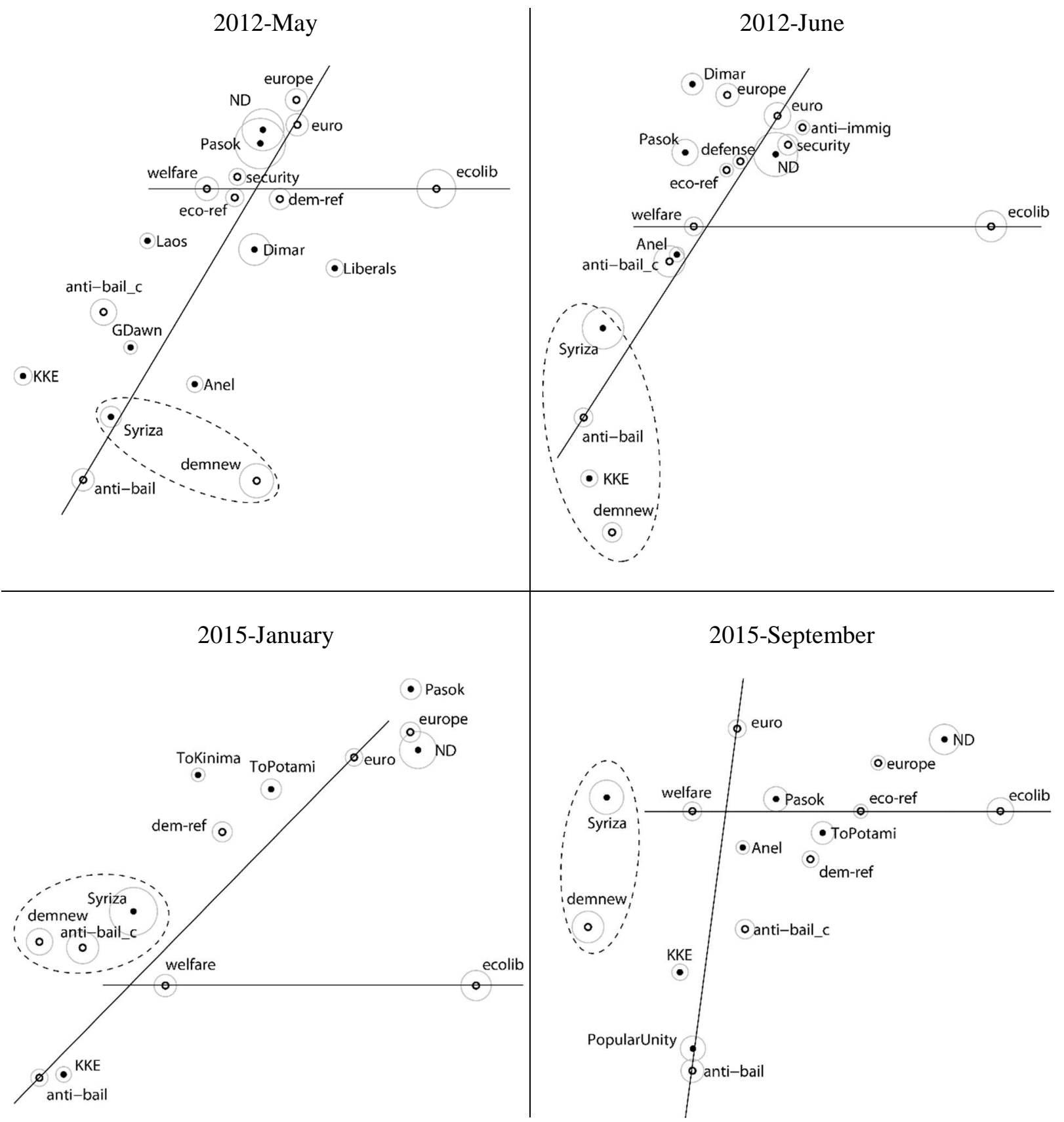

Note: The size of the circles around issues and parties indicates the relative salience of the corresponding actor or object. Abbreviated issue categories: ecolib = economic liberalism; eco-ref = economic reform (vague), demnew $=$ democratic renewal, dem-reform $=$ democratic reform (vague), antibail $=$ anti-bailout, anti-bail_c $=$ anti-bailout (conditions) (descriptions of all issue categories can be found in Table A.3)

Stress-1: 0.37 (2012 May), 0.29 (2012 June), 0.22 (2015 January), 0.28 (2015 December) 
Figure 2 continued

(b) Spain

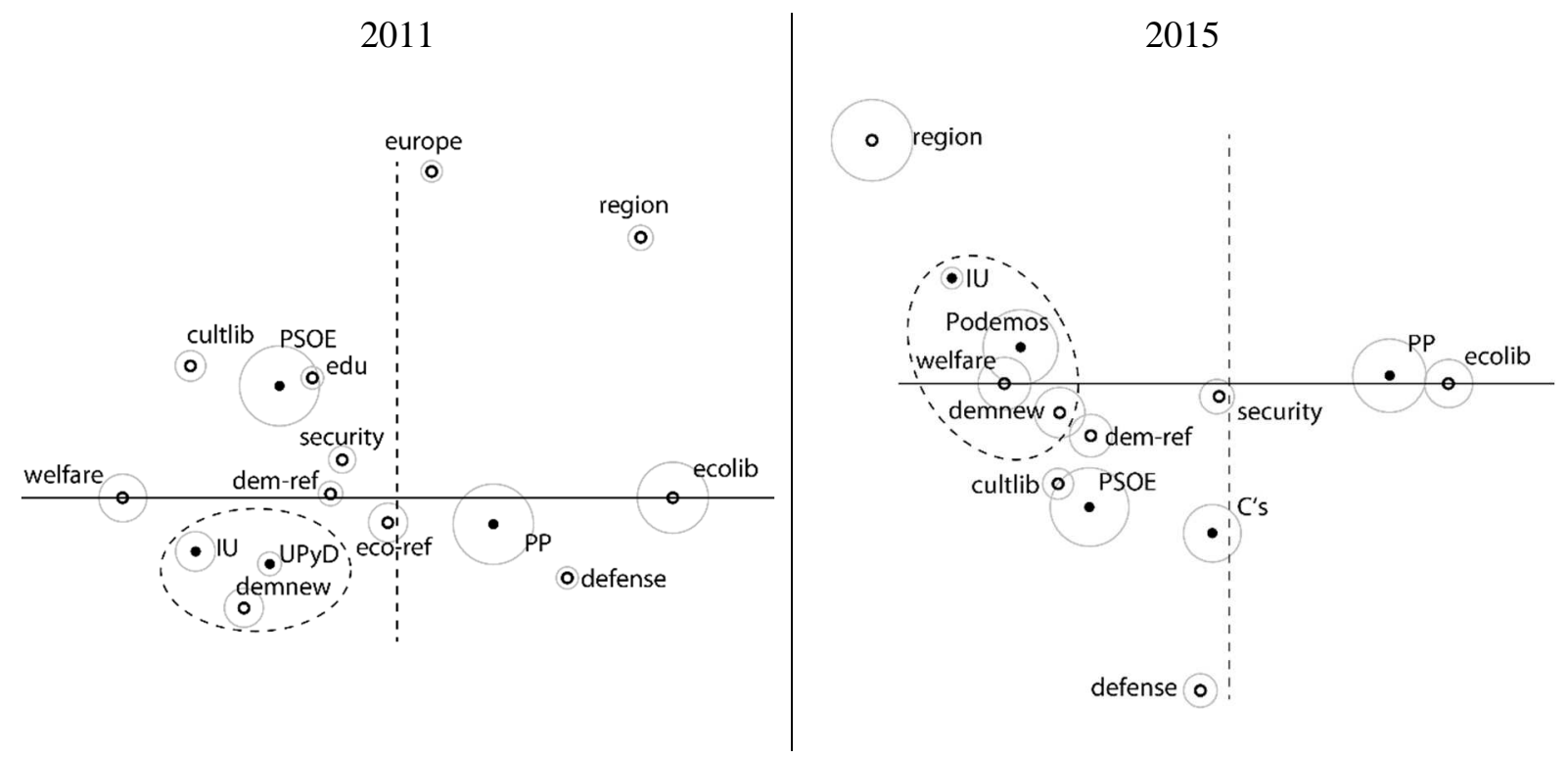

Stress-1: 0.18 (2011), 0.26 (2015) 
Figure 2 continued

(c) Italy

2013

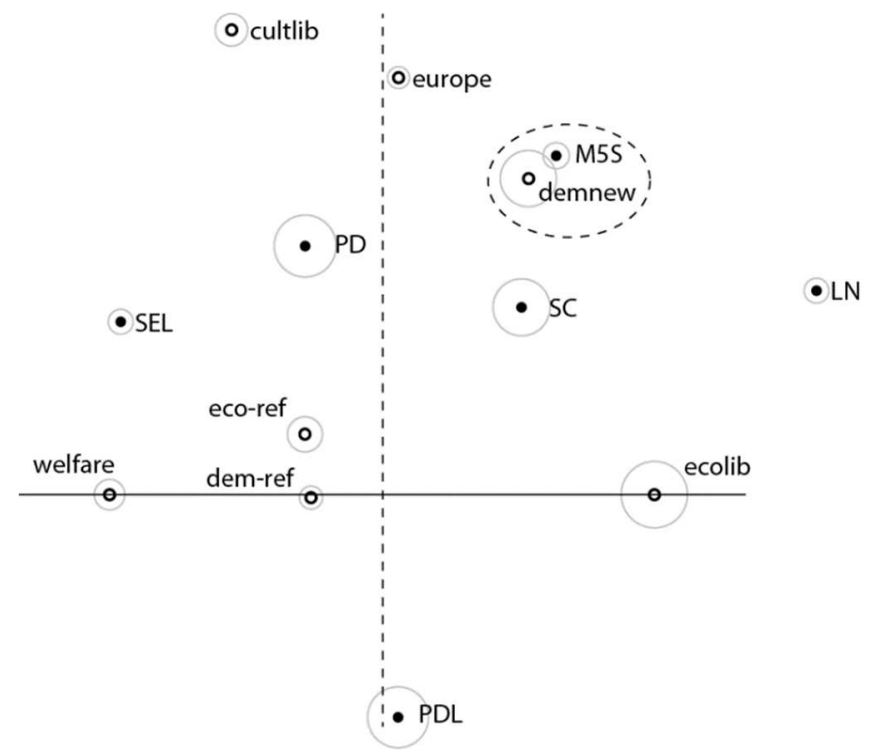

Stress-1: 0.24 
Figure 2 continued

(d) Portugal

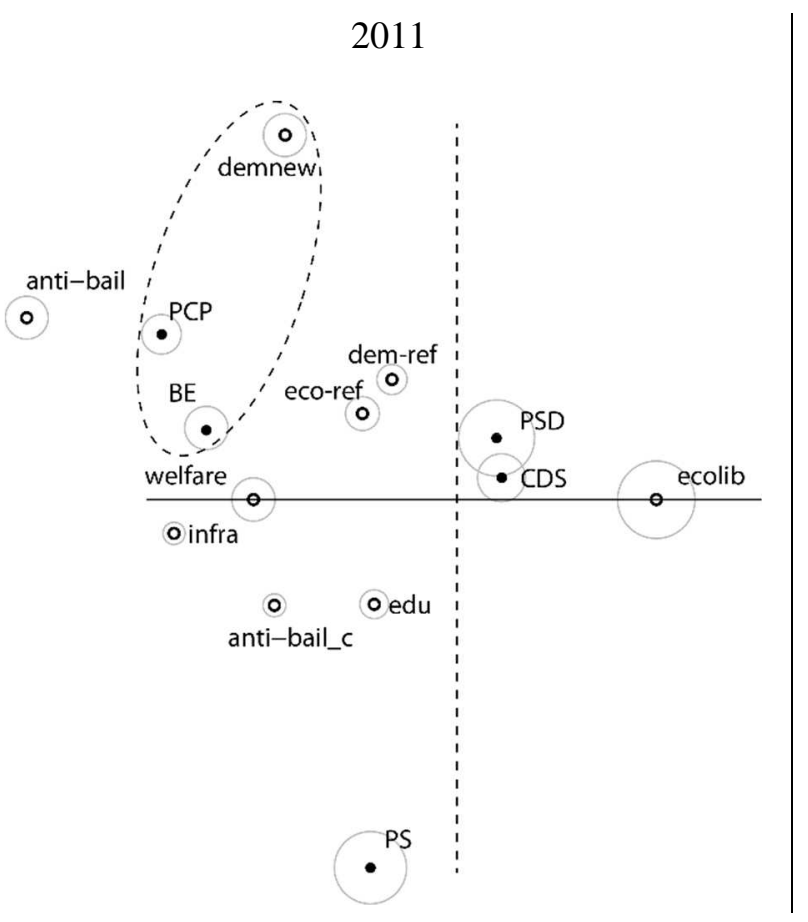

2015

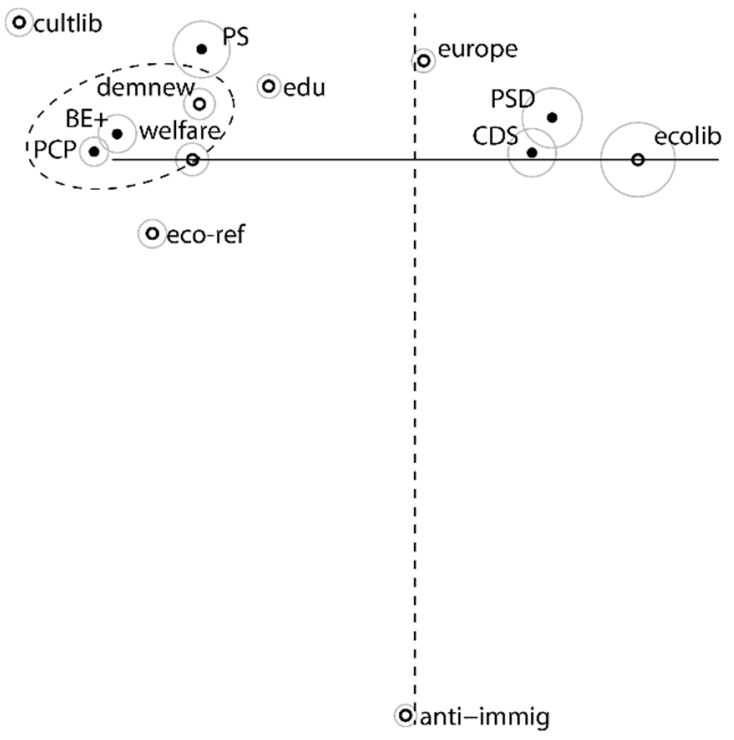

Stress-1: 0.27 (2011), 0.13 (2015) 


\section{Online Appendix}

\section{Data and methods}

While media data come with certain biases, we think they offer ample opportunities to capture changes in the political space in times of crises. More precisely, we rely on media data because we are interested in publicly visible conflicts among the parties during the campaigns. In our opinion, media data are especially sensitive to political change and allow us to examine how the issues of the day map onto underlying issue dimensions. While this might lead to limited information about small parties (as they might be underreported in the media), it gives a good indication of the conflicts and actors that dominate the public debate. Alternative data sources do not come with the same biases. However, they are usually not linked to specific elections (especially expert surveys), do not contain positional and salience measure for all issues (especially manifesto data), and apply a rather rigid issue set of issue categories (which we tend to avoid by relying on a more inductive approach to new issues).

As stated, we selected articles from two quality newspapers per country (the main center-left and center-right newspapers). We selected all news articles that were published within two months before the national Election Day and reported on the electoral contest and national party politics more generally. Editorials and commentaries were excluded from the selection. The selection was done by an extensive keyword list including the names and abbreviations of political parties and key politicians from each party. In the case of early elections, we selected the period from the announcement of the election until Election Day.

We then coded a sample of the selected articles using core sentence analysis (CSA). Following this type of relational content analysis, each grammatical sentence of an article is reduced to its most basic 'core sentence(s)' structure, which contain(s) only the subject, the object, and the direction of the relationship between the two. The core sentence approach was developed by Kleinnijenhuis and colleagues (e.g., Kleinnijenhuis, et al., 1997). This type of quantitative content analysis allows us to study both issue positions and salience. The direction between actors and issues is quantified using a scale ranging from -1 to +1 , with three intermediary positions. For example, the grammatical sentence "Party leader A rejects calls for leaving the Eurozone but supports a haircut on the country's debt" leads to two coded observations (Party A +1 Eurozone membership; Party A +1 haircut). For this paper, we only focus on relations between party actors and political issues, that is we neglect relations between different actors. The following analysis are based on a total of around 11,000 actor-issue statements, ranging from a minimum of 942 for the first Greek election in 2012 to a maximum of 1,650 for the Portuguese election in 2011 (see Table A.1).

We coded the function, party affiliation, and (if available) name of actors. For the present analysis, the actors were grouped according to their party affiliation. The issues were coded in even more detail (with more than 200 coded categories per election campaign). As described in the main text, the issues were aggregated into 18 categories that allow us to (a) capture the broad conflicts described in the previous sections and (b) compare our results to 
previous results of Kriesi et al. (2008, 2012). Descriptions of the 18 categories can be found in Table A.3. Furthermore, we indicate what a positive position regarding a given issue category indicates.

The systemic components of party competition that we are most interested in are operationalized by the salience and the polarization of the issues which represent the economic and political conflicts. Salience is measured by the share of core sentences on an issue category in percent of all sentences related to any issue. The indicator for the polarization of party positions is based on Taylor and Hermann's (1971) index and ranges from 0 to 1 (=maximum degree of polarization). The polarization of positions on a given issue category is computed as follow:

$$
\text { POLARIZATION }=\sum_{k=1}^{K} \omega_{k}\left(x_{k}-\bar{x}\right)^{2}
$$

Where $\omega_{k}$ is the salience of a particular issue category for party $\mathrm{k}, X_{k}$ is the position of party $\mathrm{k}$ on this issue category, and $\bar{X}$ is the weighted average position of all parties, where weights are provided by the party-specific salience of the issue category.

To analyze the structure of the political space and the resulting actor configuration, we combine the visibility of the actors, their issue positions and issue emphasis. To do so, we follow Kriesi et al. (2008) and rely on multi-dimensional scaling (MDS). For this analysis, we excluded issue categories with less than three percent of all statements and actors with less than 20 statements. In the case of Spain, we also dropped all regional parties to concentrate on party competition at the national level.

The aim of MDS is to obtain a graphical representation of the relative locations of a set of objects in a low-dimensional space. Starting from information on the proximities between pairs of objects, MDS finds the optimal space in which these objects can be located while distorting as little as possible the original proximities. In our case, we consider the distances between parties and issues, which were determined with the help of content analyses, and use MDS to construct a representation of the locations of these parties and issues in a (two-dimensional) space. It is not our purpose here to explain all details of MDS. Overviews of this statistical method can be found in Borg and Groenen (1997), Cox and Cox (2001), or Kruskal and Wish (1978). Rabinowitz (1975) also presents a good and simple introduction to the topic but limited to the case of nonmetric MDS. Rather, we simply want here to emphasize some of the peculiarities of the analyses we have performed, which differ from a 'standard' MDS. Most important among these are the unfolding technique and the use of weights.

Unfolding models are special cases of MDS where information is available on the proximities between objects of two different sets, but not on the proximities between objects within each of the two sets. In our analyses, we used information on the distances between parties and issues. But we had no comparable measures of the distances between pairs of parties or between pairs of issues. Such data can be analyzed with standard MDS techniques, but it means that at least half of the cells in the proximity matrix have missing values. When such data are analyzed 
with nonmetric MDS (which implies a transformation of the original proximities into rank orders, for instance), the solutions 'are subject to many potential degeneracies' (Borg and Groenen, 1997: 231). Metric MDS, however, is more robust and avoids the problems linked with nonmetric MDS in the case of unfolding (Borg and Groenen, 1997: 245ff.).

The second particularity of our MDS analyses is the use of weights. As explained above, MDS locates the objects in a space while keeping the distances between them as close as possible to the original proximities. However, as the aim is to obtain a representation of the objects in a low dimensional space, some distortion of the original distances is unavoidable. The degree of distortion is measured by a 'Stress' statistic, which is based on the sum of the squared distances between the original proximities and the proximities obtained in the solution. The higher the value of the Stress statistic, the worse is the fit between the solution and the data. The aim is thus to find the solution that minimizes the value of Stress. In our case, we want to obtain a configuration of parties and issues where the distances between them are as close as possible to those in our original data. By using weights, we allow for the possibility that some distortions of original distances have a larger impact on the value of Stress than others. In other words, we give much importance to representing some distances faithfully and less importance to the degree of distortion affecting other distances. The rationale for this is that not all relations between parties and issues have the same importance. In a campaign, parties address some issues very frequently while other issues play a minor role in their statements. Similarly, not all parties are central actors in a campaign. We account for such variation by computing weights that reflect the salience of a given party $\times$ issue relationship. These weights are calculated as the number of core sentences corresponding to a given party $\times$ relationship, expressed as a proportion of the total number of relationships between parties and issues.

\section{References}

Borg, Ingwer and Patrick Groenen (1997). Modern Multidimensional Scaling: Theory and Applications. Springer Series in Statistics. New York: Springer.

Cox, Trevor F. and Michael A. A. Cox (2001). Multidimensional Scaling. Second Edition. London: Chapman \& Hall.

Kruskal, Joseph B. and Myron Wish (1978). Multidimensional Scaling. Sage University Paper series on Quantitative Application in the Social Sciences, 07-011. Newbury Park: Sage.

Rabinowitz, George B. (1975). "An Introduction to Nonmetric Multidimensional Scaling", American Journal of Political Science 19(2): 343-390.

Taylor, Michael and V.M. Herman (1971). "Party Systems and Government Stability." American Political Science Review 65(1): 28-37. 
Table A.1: Number of actor-issue sentences per campaign

\begin{tabular}{llc}
\hline Country & Election & Number of sentences \\
\hline Greece & 2012-May & 942 \\
Greece & 2012-June & 1,027 \\
Greece & 2015-January & 1,058 \\
Greece & 2015-September & 975 \\
Italy & 2013 & 1,521 \\
Portugal & 2011 & 1,650 \\
Portugal & 2015 & 1,345 \\
Spain & 2011 & 1,151 \\
Spain & 2015 & 1,406 \\
\hline Total & 11,075 & 11,075 \\
\hline
\end{tabular}

Note: The table shows the total number of actor-issue statements used for the analysis by campaign. 
Table A.2: Issue categories

\begin{tabular}{|c|c|}
\hline Categories & Description (a position of +1 stands for ...) \\
\hline \multicolumn{2}{|l|}{ Domestic economic } \\
\hline 1. welfare & $\begin{array}{l}\text { support for an expansion of the welfare state; objection to wel- } \\
\text { fare state retrenchment; support for tax reforms with a redistribu- } \\
\text { tive character; calls for employment and health care programs }\end{array}$ \\
\hline 2. economic liberalism & $\begin{array}{l}\text { opposition to market regulation, economic protectionism in agri- } \\
\text { culture and other sectors of the economy; support for deregula- } \\
\text { tion, more competition, and privatization; support for a rigid } \\
\text { budgetary policy; reduction of the state deficit and taxes without } \\
\text { direct redistributive effects }\end{array}$ \\
\hline 3. economic reform (vague) & $\begin{array}{l}\text { support for general economic reforms without a clear direction } \\
\text { (e.g., fighting economic crisis; fighting unemployment) }\end{array}$ \\
\hline \multicolumn{2}{|l|}{ Domestic political } \\
\hline 4. democratic renewal & $\begin{array}{l}\text { support for institutional reforms to make the political system } \\
\text { more democratic or transparent; opposition to corruption and po- } \\
\text { litical class }\end{array}$ \\
\hline 5. democratic reform (vague) & $\begin{array}{l}\text { support for general reforms of the political system without clear } \\
\text { direction }\end{array}$ \\
\hline 6. regionalism & support for regional autonomy or independence \\
\hline 7. media diversity & support for equal media access and coverage of parties \\
\hline \multicolumn{2}{|l|}{ European economic } \\
\hline 8. euro & $\begin{array}{l}\text { support for the single European currency; opposition to a country } \\
\text { leaving the Eurozone }\end{array}$ \\
\hline 9. anti-bailout & opposition to the bailout \\
\hline 10. anti-bailout (conditions) & $\begin{array}{l}\text { opposition to the conditions of the bailout; support for more fa- } \\
\text { vorable conditions (e.g., better interest rates, debt restructuring) }\end{array}$ \\
\hline \multicolumn{2}{|l|}{ European political } \\
\hline 11. europe & $\begin{array}{l}\text { support for European integration in general, deepening and wid- } \\
\text { ening }\end{array}$ \\
\hline \multicolumn{2}{|l|}{ Others } \\
\hline 12. cultural liberalism & $\begin{array}{l}\text { support for cultural diversity, international cooperation, gender } \\
\text { equality, LGTB rights; opposition to national traditions and tradi- } \\
\text { tional moral values. }\end{array}$ \\
\hline 13. anti-immigration & support for restrictive immigration and integration policies \\
\hline 14. security & $\begin{array}{l}\text { support for more law and order, fighting crime (except tax fraud } \\
\text { and corruption) }\end{array}$ \\
\hline 15. defense & $\begin{array}{l}\text { support for military interventions, the armed forces, a strong na- } \\
\text { tional defense, and nuclear weapons }\end{array}$ \\
\hline 16. education & support for education and research \\
\hline 17. environment & $\begin{array}{l}\text { support for environmental protection; opposition to nuclear en- } \\
\text { ergy }\end{array}$ \\
\hline 18. infrastructure & $\begin{array}{l}\text { support for improving the country's roads, railways, and other } \\
\text { physical infrastructure; support for media }\end{array}$ \\
\hline
\end{tabular}


Table A.3: Salience of economic and political issues by election and country

\begin{tabular}{lccccc}
\hline & \multicolumn{2}{c}{ Economic } & \multicolumn{2}{c}{ Political } & Others \\
& Domestic & European & Domestic & European & \\
\hline GR 2012-May & 34.3 & 23.7 & 22.8 & 6.9 & 12.3 \\
GR 2012-June & 27.3 & 36.5 & 9.0 & 9.5 & 17.7 \\
GR 2015-Jan & 30.8 & 32.0 & 22.2 & 7.9 & 7.0 \\
GR 2015-Sept & 29.1 & 27.9 & 29.3 & 4.7 & 8.9 \\
IT 2013 & 50.0 & 1.2 & 30.6 & 3.4 & 14.8 \\
PT 2011 & 53.7 & 14.1 & 18.2 & 0.3 & 13.6 \\
PT 2015 & 64.1 & 2.9 & 10.1 & 1.7 & 21.2 \\
ES 2011 & 58.6 & 1.9 & 18.1 & 1.1 & 20.3 \\
ES 2015 & 26.6 & 1.0 & 52.2 & 0.3 & 20.0 \\
\hline
\end{tabular}

Note: The Table shows the share of an issue category in percent of all coded issues by campaign. 